\title{
IMPLEMENTASI MODEL PEMBELAJARAN THINKING ALOUD PAIR PROBLEM SOLVING (TAPPS) DAN PENDEKATAN CONTEXTUAL TEACHING AND LEARNING (CTL) UNTUK MENINGKATKAN KEMAMPUAN PEMAHAMAN KONSEP MATEMATIS SISWA SMP \\ (Studi Komparatif pada Siswa Kelas VIII SMP Negeri 3 Lembang, Bandung Barat)
}

\author{
Joice Soreani Noti \\ Guru SMP Advent Parongpong \\ joice.soreani@gmail.com
}

\begin{abstract}
Abstrak: Kemampuan pemahaman konsep adalah salah satu kemampuan yang harus dimiliki dalam pelajaran matematika. Namun kemampuan pemahaman konsep yang dimiliki siswa di Indonesia masih rendah. Penelitian ini bertujuan untuk mengetahui apakah terdapat perbedaan peningkatan antara siswa yang memperoleh pembelajaran dengan model Thingking Aloud Pair Problem Solving (TAPPS) dan yang memperoleh pendekatan Contextual Teaching and Learning (CTL). Desain dalam penelitian ini adalah desain komparatif. Sampel dalam penelitian ini adalah kelas VIII-I dan kelas VIII-J SMPN 3 Lembang. Di mana kelas VIII-I memperoleh perlakuan model pembelajaran TAPPS dan yang memperoleh pendekatan CTL kelas VIII-J. Instrumen yang digunakan adalah tes kemampuan pemahaman konsep matematis siswa yang berupa tes uraian dan angket respon siswa. Hasil dari penelitian ini menunjukkan bahwa: peningkatan kemampuan pemahaman konsep matematis pada siswa yang memperoleh pembelajaran dengan menggunakan model TAPPS dan siswa yang memperoleh pembelajaran dengan menggunakan pendekatan CTL termasuk dalam kategori sedang. Tetapi, walaupun terdapat peningkatan kemampuan pemahaman konsep siswa, perbedaan tersebut tidaklah signifikan. Temuan lain dari penelitian ini adalah bahwa siswa suka dengan model pembelajaran kooperatif tipe TAPPS dan pembelajaran dengan menggunakan pendekatan CTL yang mereka peroleh.
\end{abstract}

Kata Kunci : Kemampuan Pemahaman Konsep Matematis, Pembelajaran Kooperatif tipe Thingking Aloud Pair Problem Solving (TAPPS), Pendekatan Contextual Teaching and Learning (CTL)

\section{PENDAHULUAN}

Depdiknas RI No 22 Tahun 2006 menyatakan bahwa salah satu tujuan dalam pembelajaran matematika adalah siswa memiliki kemampuan pemahaman konsep. Pemahaman konsep merupakan salah satu kemampuan yang harus dimiliki siswa untuk dapat menguasai materi pelajaran yang sedang diajarkan. Zevika dkk (2012) menyatakan bahwa pemahaman konsep adalah hal yang diperlukan dalam mencapai hasil belajar yang baik, termasuk dalam pembelajaran matematika. Sedangkan Agustina (2016) mengemukakan bahwa pemahaman konsep merupakan tipe hasil belajar yang lebih tinggi dari pada pengetahuan. Misalnya dapat menjelaskan dengan susunan kalimatnya sendiri sesuatu yang dibaca atau didengarnya dan memberikan contoh lain dari yang telah dicontohkan. Dengan demikian siswa yang sudah memahami konsep dengan baik dapat menerjemahkan, menafsirkan, mengaitkan berbagai konsep dalam matematika dan menyimpulkan suatu konsep matematika berdasarkan pengetahuannya sendiri. 
Murizal dkk (2012) menyatakan bahwa pada kenyataannya banyak siswa yang kesulitan dalam memahami konsep matematis. Bahkan mereka kebanyakan tidak mampu mendefinisikan kembali bahan pelajaran matematika dengan bahasa mereka sendiri serta membedakan antara contoh dan bukan contoh dari sebuah konsep. Selanjutnya, Hadi dan Umi (2016) memaparkan bahwa pemahaman konsep matematis rendah. Dari hasil penelitian yang dilakukan di SMPN 1 Martapura melalui analisis kerja UTS siswa kelas VIII SMPN 1 Martapura, bahwa kurang dari 50 persen siswa belum memenuhi Kriteria Ketuntasan Minimal (KKM). Siswa keliru dalam memahami soal sehingga tidak bisa mengaplikasikan konsep dalam meyelesaikan soal. Selain itu, ketika berdiskusi kelompok hanya siswa tertentu saja yang berpartisipasi lebih aktif, sementara siswa yang lain enggan berusaha untuk mengemukakan pendapatnya.

Hal ini juga senada dengan penelitian yang dilakukan oleh Mawaddah dan Maryanti (2016) pada guru matematika SMP Negri 17 Banjarmasin menyatakan bahwa pemahaman akan konsep matematis rendah, masih banyak siswa yang belum memahami konsep tentang materi yang diajarkan sehingga matematika cenderung dianggap sebagai pelajaran yang sulit. Mereka juga melakukan pengamatan saat kegiatan belajar mengajar berlangsung dan terlihat bahwa rendahnya kemampuan pemahaman konsep matematis siswa dikarenakan pembelajaran matematika yang dilakukan guru di kelas VII lebih banyak didominasi oleh guru bukan berpusat pada siswa, sehingga respon siswa menjadi kurang baik selama di kelas, siswa cenderung pasif dan hanya mendengar apa yang guru sampaikan saja, oleh sebab itu banyak siswa yang terlihat bosan, tidak semangat dalam belajar, bahkan ada yang malas membuka buku.

Selain itu, Hutagalung (2017) menyatakan bahwa pemahaman konsep matematis siswa hingga sekarang masih tergolong rendah oleh karena siswa tidak banyak terlibat dalam mengkonstruksikan pengetahuannya dan hanya menerima informasi yang disampaikan searah dari guru, siswa tidak mampu mendefinisikan kembali bahan pelajaran matematika dengan bahasa mereka sendiri apalagi memaknai matematika dalam bentuk nyata.

Untuk mengembangkan pemahaman konsep matematis maka pembelajaran yang dilakukan di kelas harus diatur berdasarkan kebutuhan siswa yang belajar serta karakteristik materi yang akan diajarkan. Adapun alternatif pembelajaran yang dapat digunakan model pembelajaran kooperatif tipe Thinking Aloud Pair Problem Solving (TAPPS) dan pendekatan Contextual Teaching and Learning (CTL).

Model pembelajaran kooperatif tipe TAPPS mengutamakan kerja sama antar pasangan 
dalam memecahkan suatu permasalahan sehingga siswa dapat saling bertukar pikiran dalam memperbaiki pemahaman. Hal ini didukung oleh Suhendar (2014) yang menyatakan bahwa model pembelajaran TAPPS adalah teknik berfikir lisan secara berpasangan dalam penyelesaian masalah yang merupakan salah satu metode pembelajaran yang dapat menciptakan kondisi belajar aktif kepada siswa untuk memahami konsep yang dipelajarinya. Sedangkan pendekatan CTL menurut Hasibuan (2014) adalah proses pembelajaran yang bertujuan membantu siswa untuk memahami makna materi ajar dan mengaitkannya dengan konteks kehidupan mereka sehari-hari, sehingga siswa memiliki pengetahuan ataupun keterampilan yang dinamis dan fleksibel untuk mengkonstruksi sendiri secara aktif pemahamannya. Dalam hal ini siswa dapat belajar dengan baik melalui kegiatan mengalami sendiri dalam lingkungannya yang alamiah bukan hanya sekedar mendengarkan dan mencatat tetapi belajar mampu menemukan materi yang dipelajarinya.

Berdasarkan uraian diatas maka dipilih judul penelitian: "Implementasi Model Pembelajaran Thinking Aloud Pair Problem Solving (TAPPS) dan Pendekatan Contextual Teaching and Learning (CTL) untuk Meningkatkan Kemampuan Pemahaman Konsep Matematis Siswa SMP." Mengacu kepada masalah yang ada pada latar belakang masalah, maka rumusan masalah dinyatakan sebagai berikut:

1. Bagaimana peningkatan kemampuan pemahaman konsep matematis siswa yang memperoleh model pembelajaran TAPPS dan pendekatan CTL?

2. Apakah terdapat perbedaan pada peningkatan kemampuan pemahaman konsep matematis siswa SMP yang mendapat perlakuan model pembelajaran TAPPS dan pendekatan CTL?

3. Bagaimana respon belajar siswa terhadap model pembelajaran TAPPS dan pendekatan CTL?

\section{KAJIAN PUSTAKA}

\section{Thinking Aloud Pair Problem Solving (TAPPS)}

Model pembelajaran TAPPS adalah model pembelajaran kooperatif yang mengajak siswa untuk berfikir keras dalam arti berpikir dengan sunguh-sungguh secara berpasangan dalam penyelesaian masalah sehingga menciptakan kondisi belajar yang aktif. Sehingga, model pembelajaran ini membutuhkan dua orang siswa yang berperan sebagai Problem Solver (PS) dan Listener (L) untuk berdiskusi dalam menyelesaikan masalah matematis yang diberikan oleh guru. Seorang PS mengungkapkan secara lisan dan jelas segala sesuatu dari hasil pemikirannnya mengenai solusi dari masalah yang diberikan, sedangkan L mendengarkan, memberikan dorongan dan usulan jika menemui pernyataan PS yang tidak sesuai atau tidak 
dimengerti. Untuk permasalahan berikutnya PS dan L saling bertukar peran.

Berikut merupakan tugas seorang PS dan L menurut Johson dan Chung (Widiyastuti, 2014).

1. Menjadi Seorang PS

a. Membaca soal agar L mengetahui permasalahan yang akan dipecahkan.

b. PS mengemukakan semua pendapat, gagasan serta semua langkah yang akan dilakukan untuk menyelesaikan masalah kepada L.

c. Mencoba untuk terus menyelesaikan masalah sekalipun PS menganggap masalah tersebut sulit.

2. Menjadi Seorang L

a. Menuntun PS untuk terus berbicara.

b. Memastikan bahwa langkah dari solusi permasalahan yang diungkapkan oleh PS tidak ada yang salah, dan tidak ada langkah dari solusi tersebut yang hilang.

c. Membantu PS agar lebih teliti dalam mengungkapkan solusi permasalahannya.

d. Memberikan isyarat kepada PS jika PS melakukan kesalahan dalam proses berpikirnya atau dalam perhitungannya, tetapi L jangan memberikan jawaban yang benar.

Menurut Handayani dkk (2014) model pembelajaran ini bermanfaat untuk membantu siswa berlatih menyampaikan semua ide-ide yang dimiliki sesuai dengan pemahamannya dalam proses penyelesaian masalah dari hasil diskusi yang dilakukan sehingga siswa dapat menarik kesimpulan atau solusi, maka dengan menggunakan model pembelajaran TAPPS diharapkan kemampuan pemahaman konsep matematis siswa dapat meningkat.

Anwar (Zai, 2015) mengatakan bahwa langkah-langkah model pembelajaran TAPPS terdiri dari 3 yaitu :

a. Guru membagi siswa menjadi dua kelompok besar sebagai PS dan L dan menentukan pasangannya serta menjelaskan apa saja yang mereka lakukan di dalam kelompok tersebut. Guru memberitahukan kepada siswa peran PS akan mengutarakan pemahamannya dalam menyelesaikan masalah dan sebagai L mendorong untuk menyelesaikan masalah, membantu dalam menggambarkan langkahlangkah penyelesaian masalah. L juga bisa memberikan saran-saran dan pernyataan-pernyataan yang berhubungan dengan masalah yang sedang dibahas.

b. Meminta siswa menyelesaikan sejumlah soal secara bergantian peran.

c. Kegiatan akan dihentikan apabila siswa telah menyelesaikan seluruh masalah tersebut dan siswa akan mempresentasikan hasil kerja mereka. 


\section{Contextual Teaching and Learning (CTL)}

CTL membantu siswa untuk belajar lebih baik melalui kegiatan mengalami sendiri dalam lingkungan yang alamiah. Marwanto dkk (2017) menyatakan bahwa model CTL memotivasi siswa untuk menghubungkan pengetahuan dengan menerapkannya dalam kehidupan seharihari sehingga diharapkan dapat meningkatkan pemahaman siswa.

Selain itu CTL mengusahakan untuk membuat siswa aktif dalam menggali kemampuan dirinya (Faulina dan Fitria : 2017). Sehingga, dapat dikatakan bahwa pembelajaran CTL lebih berpusat pada siswa. Tiga hal yang harus dipahami dalam CTL yaitu : 1) CTL mendorong siswa untuk dapat menerapkan konsep dalam kehidupan, artinya CTL bukan hanya mengharapkan siswa dapat memahami materi yang dipelajarinya, akan tetapi bagaimana materi pelajaran itu dapat mewarnai perilakunya dalam kehidupan seharihari, 2) CTL menekankan kepada proses keterlibatan siswa untuk menemukan materi, artinya proses belajar diorientasi pada proses pengalaman secara langsung, 3) CTL mendorong siswa agar dapat menemukan hubungan antara materi yang dipelajari dengan situasi kehidupan nyata, artinya siswa dituntut untuk dapat menangkap hubungan pengalaman belajar di sekolah dengan kehidupan nyata.

Hutagaol (2013), Hasibuan (2014) dan Triyanto (dalam Indriani : 2017) mengemukakan tujuh komponen pembelajaran kontekstual yaitu konstruktivisme, penemuan, bertanya, masyarakat belajar, pemodelan, refleksi, dan penilaian otentik.

1. Konstruktivisme (constructivism) Konstruktivisme adalah proses membangun atau menyusun pengetahuan baru dalam struktur kognitif siswa berdasarkan pengalaman. Oleh karena pengetahuan itu tidak dapat dipindahkan secara utuh dari pikiran guru ke siswa, namun secara aktif dibangun oleh siswa sendiri melalui pengalaman nyata (Novia dan Kusumo : 2013)

2. Menemukan (inquiry) Inkuiri ialah proses pembelajaran didasarkan pada pencarian dan menemukan melalui proses berpikir secara sistematis.

3. Bertanya (questioning) Bertanya berarti mendorong siswa untuk tidak menerima teori secara mentah tetapi membantu siswa untuk mengembangkan sikap ingin tahunya tentang teori yang dipelajari.

4. Masyarakat belajar (learning community) Konsep masyarakat belajar dalam CTL menyarankan agar hasil pembelajaran diperoleh melalui hasil kerjasama dengan orang lain, baik dalam kelompok belajar secara formal maupun dalam lingkungan yang terjadi secara ilmiah.

5. Pemodelan (modeling) Pemodelan adalah proses pembelajaran dengan memperagakan sesuatu sebagai contoh yang dapat ditiru oleh setiap siswa. 
6. Refleksi (reflection) Refleksi adalah proses aplikasi pengalaman yang telah dipelajari dengan cara mengurutkan kembali peristiwa pembelajaran yang telah dilaksanakan.

7. Penilaian Otentik (authentic assessment). Penilaian CTL tidak hanya dilakukan oleh aspek hasil belajar tes akan tetapi juga proses belajar melalui penilaian nyata. Penilaian nyata adalah proses yang dilakukan guru untuk mengumpulkan informasi tentang perkembangan belajar yang dilakukan siswa (percaya diri dalam menyampaikan pemahamannya terkait materi yang dipelajari), baik dari segi pengetahuan dan keterampilan, dan tugas-tugas yang relevan dengan kontekstual.

Dari tujuh komponen maka langkah-langkah penerapan CTL dalam kelas yaitu:

1. Mengembangkan pemikiran siswa bahwa belajar lebih bermakna dengan cara bekerja, menemukan, dan mengkonstruksikan sendiri pengetahuan dan keterampilan barunya.

2. Melaksanakan kegiatan inquiri untuk pembelajaran yang dilaksanakan.

3. Mengembangkan sifat ingin tahu siswa dengan bertanya.

4. Menciptakan masyarakat belajar dalam kelompok yang heterogen.

5. Menghadirkan model sebagai contoh pembelajaran.

6. Melakukan refleksi di akhir pertemuan.

7. Melakukan penilaian yang sebenarnya dengan berbagai cara.

Peranan guru dalam menggunakan pendekatan CTL adalah membimbing siswa agar bisa belajar dengan tahap perkembangannya, memilih materi belajar yang dianggap penting untuk dipelajari oleh siswa, membantu agar setiap siswa mampu menemukan keterkaitan antara pengalaman baru dengan pengalaman sebelumnya, memfasilitasi agar siswa mampu melakukan proses memahami pengalaman-pengalaman baru dari segi skema yang ada (asimilasi) dan mengubah skema yang ada agar sesuai dengan situasi baru (akomodasi).

\section{METODE PENELITIAN}

Studi komparatif merupakan desain penelitian yang akan digunakan di mana studi ini membandingkan dua kelas yang menggunakan pembelajaran yang berbeda. Kelas pertama diberi model pembelajaran Kooperatif tipe Thinking Aloud Pair and Problem Solving (TAPPS) sedangkan kelas kedua diberi pendekatan Contextual Teaching and Learning (CTL). Adapun desain penelitian menurut Fraenkel dan Wallen ditunjukkan pada Tabel 1.

Tabel 1. Desain Penelitian

\begin{tabular}{|c|c|c|}
\hline Kelompok & Variabel Bebas & Pengukuran \\
\hline $\mathrm{K}_{1}$ & $\mathrm{X}_{1}$ & $\mathrm{O}$ \\
\hline $\mathrm{K}_{2}$ & $\mathrm{X}_{2}$ & $\mathrm{O}$ \\
\hline
\end{tabular}




\section{Keterangan:}

$\mathrm{K}_{1} \quad$ : Kelompok kelas pertama

$\mathrm{K}_{2} \quad$ : Kelompok kelas kedua

$\mathrm{O} \quad$ : Gain kemampuan pemahaman konsep

$\mathrm{X}_{1}$ : Model pembelajaran kooperatif tipe TAPPS

$\mathrm{X}_{2} \quad$ : Pendekatan CTL

Populasi dalam penelitian ini adalah siswa SMP Negeri 3 Parongpong di Kabupaten Bandung Barat. Sedangkan yang menjadi sampel dalam penelitian ini adalah kelas VIII-I dengan banyak siswa 30 orang, sebagai kelompok 1 yang memperoleh model pembelajaran Kooperatif tipe Thinking Aloud Pair Problem Solving (TAPPS), sedangkan untuk kelompok 2 yang memperoleh pembelajaran dengan pendekatan Contextual Teaching and Learning (CTL) adalah kelas VIII-J dengan banyak siswa 30 orang.

Instrumen penelitian yang digunakan dalam penelitian ini adalah instrumen tes dan non-tes. Instrumen tes terdiri dari pretest dan post-test, sedangkan insrtrumen nontes berupa angket (respon siswa tehadap model pembelajaran TAPPS dan pendekatan CTL, serta kemampuan pemahaman konsep matematis dan matematika). Instrumen penelitian ini dilakukan untuk mendapatkan data dan informasi yang lengkap untuk memenuhi kajian dalam penelitian.

\section{HASIL DAN PEMBAHASAN}

Hasil penelitian yang telah dilakukan oleh penulis disajikan dalam bentuk deskripsi statistik. Dengan menguraikan statistik kemampuan awal siswa (pretest) yang memperoleh model pembelajaran kooperatif tipe Thinking Aloud Pair Problem Solving (TAPPS) dan siswa yang memperoleh pendekatan Contextual Teaching and Learning (CTL), kemampuan akhir (posttest) siswa yang memperoleh model pembelajaran TAPPS dan siswa yang memperoleh pembelajaran dengan pendekatan CTL, peningkatan (gain ternormalisasi) kemampuan pemahaman konsep matematis siswa, serta hasil respon siswa terhadap model pembelajaran TAPPS dan pendekatan CTL. Hal ini dilakukan untuk mengumpulkan informasi tentang kemampuan pemahaman konsep matematis siswa yang memperoleh model pembelajan TAPPS dan siswa yang memperoleh pembelajaran dengan pendekatan CTL. Data yang ada diolah menggunakan software SPSS versi 14,0.

\section{Deskripsi Tes Awal (Pretest)}

Hasil pretest dari kemampuan awal pemahaman konsep matematis siswa pada kedua kelompok ditunjukkan pada Tabel 2.1. 
Tabel 2.1. Deskripsi Tes Awal (Pretest)

\begin{tabular}{|c|c|c|}
\hline Keterangan & TAPPS & CTL \\
\hline Ukuran Sampel & 30 & 30 \\
\hline Nilai Rata-Rata & 9,30 & 9,73 \\
\hline Std. Deviasi & 3,91 & 4,20 \\
\hline
\end{tabular}

SMI $=32$

Pada Tabel 4.1 menunjukkan bahwa rata-rata nilai pretest kemampuan pemahaman konsep matematis siswa yang memperoleh model pembelajaran TAPPS sebesar 9,30 sedangkan rata-rata nilai pretest kemampuan pemahaman konsep matematis siswa yang memperoleh pembelajaran dengan pendekatan CTL sebesar 9,73. Artinya, rata-rata nilai pretest kemampuan konsep matematis siswa pada kedua kelompok tersebut masih rendah karena masih jauh dari Skor Maksimum Ideal (SMI = 32). Hal ini terjadi karena mereka belum mempelajari materi tersebut.

\section{Deskripsi Tes Akhir (Posttest)}

Hasil posttest dari kemampuan akhir pemahaman konsep matematis siswa pada kedua kelompok setelah diberikan perlakuan dapat dilihat pada Tabel 2.2.

Tabel 2.2. Deskripsi Tes Akhir (Posttest)

\begin{tabular}{|c|c|c|}
\hline Keterangan & TAPPS & CTL \\
\hline Ukuran Sampel & 30 & 30 \\
\hline Nilai Rata-Rata & 18,93 & 20,40 \\
\hline Std. Deviasi & 3,59 & 4,82 \\
\hline
\end{tabular}

SMI $=32$

Berdasarkan Tabel 2.2 dapa disimpulkan bahwa setelah diberikan perlakuan, maka nilai rata-rata pada posttest untuk kedua kelompok tersebut sudah lebih baik dari hasil pretest.

\section{Deskripsi Data Gain Ternormalisasi}

Tabel 2.3. Deskripsi Data Gain Ternormalisasi

\begin{tabular}{|c|c|c|}
\hline Keterangan & TAPPS & CTL \\
\hline Ukuran Sampel & 30 & 30 \\
\hline Nilai Rata-Rata & 0,42 & 0,49 \\
\hline Std. Deviasi & 0,13 & 0,16 \\
\hline
\end{tabular}

Berdasarkan Tabel 4.3 menunjukkan bahwa nilai rata-rata gain ternormalisasi kemampuan pemahaman konsep matematis siswa kelompok model pembelajaran TAPPS sebesar 0,42. Sedangkan nilai rata-rata gain ternormalisasi kelompok dengan pendekatan CTL sebesar 0,49. Hal ini menunjukkan bahwa peningkatan kemampuan pemahaman konsep matematis siswa pada kedua kelompok masuk dalam kategori sedang dilihat dari indeks gain $(0,30<\mathrm{g} \leq 0,70)$. 


\section{Analisis Kemampuan Pemahaman Konsep Matematis Pretest Siswa}

Analisis ini dilakukan untuk mengetahui kondisi awal kedua kelompok.

Tabel 2.4 Hasil Uji Normalitas Pretest

\begin{tabular}{|c|c|c|c|c|}
\hline \multirow{2}{*}{ Kelompok } & \multicolumn{3}{|c|}{ Shapiro-Wilk } & \multirow{2}{*}{ Keterangan } \\
\cline { 2 - 4 } & Statistic & Df & Sig. & \\
\hline TAPPS & 0,955 & 30 & 0,224 & $\mathrm{H}_{0}$ tidak ditolak \\
\hline CTL & 0,974 & 30 & 0,667 & $\mathrm{H}_{0}$ tidak ditolak \\
\hline
\end{tabular}

Berdasarkan pada Tabel 2.4 nilai signifikan pretest dari kedua kelompok tersebut menunjukkan lebih besar dari 0,05. Hal ini berarti uji normalitas pretest dari kedua kelompok tersebut berdistribusi normal.

\section{Uji Homogenitas Pretest}

Tabel 2.5 Hasil Uji Homogenitas Pretest

\begin{tabular}{|c|c|c|c|}
\hline Levene Statistic & Df $\mathbf{1}$ & Df 2 & Sig. \\
\hline 0,080 & 1 & 52 & 0,0778 \\
\hline
\end{tabular}

Berdasarkan hasil uji homogenitas pada Tabel 4.5 terlihat bahwa nilai signifikan pretest lebih besar dari 0.05 oleh sebab itu tidak ditolak, sehingga pretest dari kedua kelompok kelas tersebut adalah homogen.

\section{Uji Beda Dua Rata-Rata Pretest}

Setelah mendapatkan hasil uji homogenitas kedua data berdistribusi homogen. Selanjutnya adalah analisis dua beda rata-rata dengan uji statistik parametrik, karena kedua kelompok kelas berdistribusi normal. Hasil uji beda dua rata-rata ditunjukkan pada Tabel 2.6.

Tabel 2.6 Hasil Uji Beda Dua Rata-Rata Pretest

\begin{tabular}{|c|c|c|c|c|c|}
\hline \multirow{3}{*}{ Pretest } & \multicolumn{2}{|c|}{ Levene's Test for Equality of Variances } & \multicolumn{3}{|c|}{ T-test for Equality of Means } \\
\cline { 2 - 6 } & $\mathrm{F}$ & Sig. & $\mathrm{t}$ & $\mathrm{df}$ & Sig. (2 tailed) \\
\cline { 2 - 6 } & 0,080 & 0,0778 & $-0,413$ & 58 & 0,681 \\
\hline
\end{tabular}

Dilihat dari hasil Tabel 4.6 nilai signifikasi (2-tailed) lebih besar dari 0.05 maka tidak ditolak. Hal ini berarti, kondisi kemampuan awal dari kedua kelompok kelas tidak berbeda secara signifikan. Dengan demikian dapat dilakukan perlakuan kepada kedua kelompok tersebut.

\section{Analisis Data Gain Ternormalisasi}

Analisis data gain bertujuan untuk mengetahui peningkatan kemampuan pemahaman konsep matematis siswa pada dua kelompok kelas yang mendapat perlakuan pengajaran yang berbeda. 


\section{Uji Normalitas Gain}

\section{Ternormalisasi}

Pengujian normalitas pada nilai gain ternormalisasi dilakukan dengan uji Shapiro-Wilk dengan menggunakan bantuan software SPSS versi 14.0 for windows untuk mengetahui apakah data gain ternormalisasi berdistribusi normal atau tidak, yaitu nilai gain ternormalisasi pada siswa yang memperoleh model pembelajaran kooperatif tipe TAPPS dan pendekatan CTL. Setelah diolah, maka diperoleh hasil yang ditunjukkan pada Tabel 2.7.

Tabel 2.7 Hasil Uji Normalitas Gain Ternormalisasi

\begin{tabular}{|c|c|c|c|c|}
\hline \multirow{2}{*}{ Kelompok } & \multicolumn{3}{|c|}{ Shapiro-Wilk } & \multirow{2}{*}{ Keterangan } \\
\cline { 2 - 4 } & Statistic & Df & Sig. & \\
\hline TAPPS & 0,964 & 30 & 0,398 & $\mathrm{H}_{0}$ tidak ditolak \\
\hline CTL & 0,958 & 30 & 0,283 & $\mathrm{H}_{0}$ tidak ditolak \\
\hline
\end{tabular}

Berdasarkan pada Tabel 2.7 nilai signifikan gain ternomalisasi dari kedua kelompok tersebut lebih dari 0,05. Maka dapat dikatakan bahwa populasi data gain ternormalisasi kedua kelompok tersebut berdistribusi normal.

\section{Uji Homogenitas Gain}

Setelah mendapatkan uji normalitas kedua data berdistribusi normal, selanjutnya adalah uji homogenitas untuk mengetahui apakah model pembelajaran kooperatif tipe TAPPS dan pendekatan CTL berasal dari kelompok yang memiliki homogen atau tidak. Maka dilakukan uji Levene, dengan menggunakan bantuan software SPSS versi 14.0 for windows. Setelah diolah, maka diperoleh hasil yang ditunjukkan pada Tabel 2.8.

Tabel 2.8 Hasil Uji Homogenitas Gain Ternormalisasi

\begin{tabular}{|c|c|c|c|c|}
\hline Levene Statistic & Df 1 & Df 2 & Sig. & Keterangan \\
\hline 0,278 & 1 & 30 & 0,600 & $\mathrm{H}_{0}$ tidak ditolak \\
\hline
\end{tabular}

Berdasarkan Tabel 2.8 terlihat bahwa nilai signifikan gain ternormalisasi lebih besar dari 0,05 oleh sebab itu tidak ditolak, sehingga data gain ternormalisasi dari kedua kelompok kelas tersebut memiliki varians yang homogen.

\section{Uji Beda Dua Rata-Rata Gain Ternormalisasi}

Untuk menguji beda dua rata-rata gain ternormalisasi dari kedua kelompok kelas, maka syarat normalitas dan kehomogenan data harus terpenuhi. Karena kedua-duanya berdistribusi normal dan homogen, maka selanjutnya dilakukan uji beda dua rata-rata gain ternormalisasi dengan uji statistik parametik. Dengan menggunakan bantuan software SPSS versi 14.0 for windows. Setelah diolah, maka diperoleh hasil seperti pada Tabel 2.9. 
Tabel 2.9 Hasil Uji Beda Dua Rata-Rata Gain Ternormalisasi

\begin{tabular}{|c|c|c|c|c|c|c|c|c|c|c|}
\hline & $\begin{array}{c}\text { Ler } \\
\text { Te } \\
\text { Eq } \\
\text { Var }\end{array}$ & $\begin{array}{l}\text { e's } \\
\text { for } \\
\text { lity } \\
\text { aces }\end{array}$ & \multicolumn{7}{|c|}{ T-test for Equality of Means } \\
\hline & & \multirow[t]{2}{*}{$\mathrm{F}$} & \multirow[t]{2}{*}{ Sig. } & \multirow[t]{2}{*}{$\mathrm{t}$} & \multirow[t]{2}{*}{ df } & \multirow{2}{*}{$\begin{array}{c}\text { Sig. } \\
(2- \\
\text { tailed } \\
\quad) \\
\end{array}$} & \multirow{2}{*}{$\begin{array}{c}\text { Mean } \\
\text { Differenc } \\
\mathrm{e}\end{array}$} & \multirow{2}{*}{$\begin{array}{c}\text { Std. Error } \\
\text { Differenc } \\
\mathrm{e}\end{array}$} & \multicolumn{2}{|c|}{$\begin{array}{l}95 \% \text { Confidence } \\
\text { Interval of the } \\
\text { Diverence }\end{array}$} \\
\hline & & & & & & & & & Lower & Upeer \\
\hline $\begin{array}{c}\text { Gai } \\
\mathrm{n}\end{array}$ & $\begin{array}{l}\text { Equal } \\
\text { variance } \\
\mathrm{s} \\
\text { assumed }\end{array}$ & $\begin{array}{c}0,27 \\
8\end{array}$ & $\begin{array}{c}0,60 \\
0\end{array}$ & $\begin{array}{c}- \\
1,70 \\
9\end{array}$ & $\begin{array}{l}5 \\
8\end{array}$ & 0,093 & $-0,6603$ & 0,3846 & $\begin{array}{c}- \\
0,1433 \\
8\end{array}$ & $\begin{array}{c}0,0113 \\
3\end{array}$ \\
\hline
\end{tabular}

Dilihat dari hasil Tabel 2.9, signifikasi (2-tailed) lebih besar dari 0.05 maka tidak ditolak. Hal ini berarti, tidak ada perbedaan yang signifikan pada peningkatan kemampuan pemahaman konsep matematis siswa yang memperoleh model pembelajaran TAPSS dan siswa yang memperoleh pembelajaran dengan pendekatan CTL.

\section{Angket Respon Siswa}

Berikut ini adalah hasil dari angket respon siswa terhadap pembelajaran yang telah diterapkan pada kelas masing-masing. Angket respon ini diberikan setelah melakukan posttest terhadap kelas masing-masing.

Hasil respon kelompok kelas yang mendapatkan model pembelajaran kooperatif TAPPS memiliki presentase sebesar 74,44 \% dalam kategori "suka” begitu juga dengan respon siswa terhadap pendekatan CTL. Sedangkan hasil respon terhadap matematika, siswa yang mendapat model pembelajaran TAPPS "suka" matematika sedangkan dengan pendekatan CTL "biasa". Dan didapati bahwa respon siswa terhadap kemampuan pemahaman konsep matematis siswa pada kelompok kelas yang mendapat model pembelajaran TAPPS sebesar 66,67 \% kategori "suka" dan kelompok kelas pendekatan CTL sebesar 57,59 \% kategori "biasa."

Berdasarkan hasil penelitian di atas, maka hasil tes kemampuan pemahaman konsep matematis siswa dapat dijelaskan bahwa ada peningkatan yang terjadi pada kemampuan pemahaman konsep matematis siswa antar siswa yang mendapat model pembelajaran TAPPS dengan siswa yang mendapat pembelajaran pendekatan CTL dilihat dari hasil pretest meningkat kepada hasil posttest. Selanjutnya, tidak terdapat perbedaan peningkatan kemampuan pemahaman konsep matematis pada siswa yang memperoleh model pembelajaran TAPPS dengan siswa yang memperoleh pembelajaran dengan pendekatan CTL. Peningkatan yang diperoleh pada gain ternormalisasi untuk kedua kelompok kelas berada pada kategori sedang jika dilihat dari kriteria indeks gain ternormalisasi. Dilihat dari rata-rata respon positif 
siswa terhadap model pembelajaran TAPPS 74,44 \% dan pedekatan CTL 72,78 \% dengan selisih 1,66 \% maka dapat terlihat bahwa peningkatan belajar siswa tidak jauh berbeda. Begitu juga dengan ekstrakulikuler yang diikuti oleh beberapa siswa dari kedua kelas di tempat peneliti melakukan penelitian yang menjadi salah satu penyebab mengapa tidak ada perbedaan peningkatan hasil belajar dari kedua kelas karena mereka harus membagi waktu dan tenaga untuk mengikuti kegiatan ektrakulikuler tersebut.

Respon siswa terhadap pembelajaran matematika dengan menggunakan model pembelajaran kooperatif tipe TAPSS berada pada kategori suka yang berarti model pembelajaran kooperatif tipe TAPSS disenangi dalam penerapannya pada pelajaran matematika begitu juga pembelajaran dengan pendekatan CTL berada pada kategori suka.

\section{KESIMPULAN DAN SARAN}

\section{Kesimpulan}

Kesimpulan dari hasil pengolahan data penelitian dan pembahasan antara lain :

1. Peningkatan kemampuan pemahaman konsep matematis siswa melalui model pembelajaran kooperatif tipe Thinking Aloud Pair Problem Solving (TAPPS) dan pendekatan Contextual Teaching and Learning (CTL) berada pada kategori sedang.

2. Tidak ada perbedaan terhadap peningkatan kemampuan pemahaman konsep matematis siswa melalui model pembelajaran kooperatif tipe TAPSS dan pendekatan CTL, artinya walaupun terdapat peningkatan kemampuan pemahaman konsep siswa, perbedaan tersebut tidaklah signifikan.

3. Respon siswa terhadap pembelajaran matematika dengan mengunakan model pembelajaran kooperatif tipe TAPPS dan pembelajaran dengan pendekatan CTL berada pada kategori suka yang berarti dalam penerapannya pelajaran matematika disenangi oleh siswa.

\section{Saran}

Berdasarkan hasil penelitiaan dan kesimpulan, maka penulis merekomendasikan beberapa saran yang berhubungan dengan penelitian yang dilakukan berikut :

1. Guru dapat menggunakan model pembelajaran kooperatif tipe TAPPS dan pembelajaran dengan pendekatan CTL sebagai salah satu alteratif untuk membuat pembelajaran matematika tidak membosankan.

2. Dalam menerapkan model pembelajaran TAPPS siswa dapat terlibat dalam mengkonstruksikan pengetahuannya sehingga siswa tidak hanya menerima informasi 
yang disampaikan searah dari guru. Di mana siswa saling bertukar pikiran dalam menyelesaikan permasalahan dengan pemahaman konsepnya. Namun, sebelum dimulainya diskusi antara PS dan L, alangkah baiknya guru sudah memberikan kunci jawaban permasalahan tersebut kepada L, sehingga ia dapat memastikan langkah yang diungkapkan oleh PS tidak ada yang salah, dengan catatan L tidak memberikan jawaban yang benar.

3. Guru perlu memberikan arahan kepada PS untuk tidak bertanya selama ia menyelesaikan permasalahannya, ia perlu mencoba mengerjakan terlebih dahulu menurut pemahamannya, sebab untuk mengetahui jawaban yang benar guru akan menjelaskannya setelah kegiatan diskusi.

4. Pendekatan CTL dapat diterapkan guru dalam pembelajaran matematis oleh karena siswa menyukai halhal yang nyata dalam kehidupan sehari-hari dan membantu siswa untuk memahami permasalahan yang diberikan. Jika guru ingin membuat kelompok diskusi bagi siswa dalam menyelesaikan soal, diharapkan agar tetap konsisten dengan pembagian kelompok yang telah direncanakan oleh guru.

5. Hasil penelitian ini kiranya dapat menjadi referensi bagi pembaca khususnya peneliti yang lain untuk penelitian yang lebih lanjut dengan aspek kemampuan penelitian yang berbeda.

\section{DAFTAR PUSTAKA}

Agustina (2016). Upaya Meningkatkan Kemampuan Pemahaman Konsep dan Pemecahan Masalah Matematika Siswa SMP Negeri 4 Sipirok Kelas VII melalui Pendekatan Matematika Realistik (PMR). Dalam Jurnal Eksakta. Vol 1 (1), 2016. Tersedia http://jurnal.umtapsel.ac.id/index.php/eksakta/ article/view/49/50

Arikunto (2012). Dasar-dasar Evaluasi Pendidikan Edisi ke 2: Cetakan ke 1. Jakarta: PT Bumi Aksara.

Cahyani (2016). Penggunaan Pembelajaran Kooperatif tipe Fishbowl dan tipe Time Token Arends (TTA) untuk Meningkatkan Kemampuan Komunikasi Matematis Siswa. Skripsi. Bandung: UNAI.

Faulina dan Fitria (2017). Pengaruh Model Pembelajaran Contextual Teaching and Learning (CTL) dengan Pendekatan Icare terhadap Hasil Belajar Teknologi Informasi dan Komunikasi. Dalam Jurnal Bimbingan dan Konseling. Vol 3 (1), 2017.

Hadi dan Umi (2016). Pemahaman Konsep Matematika Siswa SMP melalui Penerapan Model Pembelajaran Kooperatif tipe Memeriksa Berpasangan (Pair Checks). Dalam EDUMAT Jurnal Pendidikan Matematika. Vol 3 (1), 2015. Tersedia http://download.portalgaruda.org/article.php? article=444224\&val=9364\&title=Pemaha man\%20Konsep\%20Matematika\%20Siswa\%20SMP\%20Melalui\%20Penerapan\%20M odel\%20Pembelajaran\%20Kooperatif\%20Tipe\%20Memeriksa\%20Berpasangan\%20(P air\%20Checks)

Hake, R.R. 2007. Design Based Research in Physich Education Research. Tersedia: 
www.physics.indiana.edu

Handayani dkk (2014). Pengaruh Metode Think Aloud Pair Problem Solving (TAPPS) terhadap Kemampuan Komunikasi Matematika Siswa SMA. Dalam Jurnal Pendidikan Matematika. Vol 3 (1), 2014.

Hasibuan (2014). Model Pembelajaran CTL (Contextual Teaching and Learning). Logaritma Vol. II, No.01 Januari 2014.

Hutagalung (2017). Peningkatan Kemampuan Pemahaman Konsep Matematis Siswa melalui Pembelajaran Guided Discovery Berbasis Budaya Toba di SMP Negeri Itukka. Dalam Journal of Mathematics Education and Science. Vol. 2, No.2 April 2017.

Hutagaol (2013). Pembelajaran Kontekstual untuk Meningkatkan Kemampuan Representasi Matematis Siswa Sekolah Menengah Pertama. Infinity Vol. II, No.1 Februari 2013.

Indriani Ari (2017). Desain Pendekatan Kontekstual pada Pembelajaran Statistik Matematika. Aksioma Vol. 8, No.1, Juli2017.

Jamaluddin dan Asto (2015). Pengaruh Model Pembelajaran CTL (Contextual Teaching and Learning) terhadap Hasil Belajar Siswa pada Kompetensi Dasar Menerapkan Macammacam Gerbang Dasar Rangkai Logika di SMK Negeri 7 Surabaya. Dalam Jurnal Pendidikan Teknik Elektro. Vol 4 (1), 2015.

Lilies (2016). Implementasi Model Pembelajaran Kooperatif tipe Murder dan Pendekatan Pembelajaran Open-Ended untuk Meningkatkan Kemampuan Pemecahan Masalah Matematis Siswa SMA. Skripsi. Bandung: UNAI.

Marlina (2017). Model Pembelajaran Kooperatif tipe Co-op co-op dan Group to Group Exchange (GGE) untuk Meningkatkan Kemampuan Koneksi Matematis Siswa SMP. Skripsi. Bandung: UNAI.

Marwanto dkk (2017). Penerapan Model Contextual Teaching Learning (CTL) dalam Peningkatan Pembelajaran Bangun Ruang (siswa Kelas V SD Negeri 2 Pejagatan Tahun Ajaran 2013/2014).

Mawaddah dan Maryanti (2016). Kemampuan Pemahaman Konsep Matematika Siswa SMP dalam Pembelajaran Menggunakan Model Penemuan Terbimbing (Discovery Learning). Dalam EDU-MAT Jurnal Pendidikan Matematika. Volume 4, Nomor 1, April 2016, hlm $76-85$.

Murizal dkk (2012). Pemahaman Konsep Matematis dan Model Pembelajaran Quantum Teaching. Dalam Jurnal Pendidikan Matematika. Vol 1 (1), 2012, Hal. 19-23.

Mutohar (2016). Analisis Kemampuan Pemahaman Konsep Matematis Siswa Kelas IX SMP Negeri 1 Pandanarum pada Materi Kesebangunan dan Kekongruenan. Bachelor thesis, Universitas Muhammadiyah Purwokerto. [Online]. Available: http://repository.ump.ac.id/90/4 /ALI\%20MUTOHAR\%20BA B\%20II.pdf

Naryestha dkk (2014). Model Pembelajaran Kooperatif TAPPS Berbantuan LKS Berpengaruh terhadap Hasil Belajar Matematika. Dalam eJournal Mimbar PGSD Universitas Pendidikan Ganesha Jurusan PGSD. Vol 2 (1), 2014. Tersedia http://download.portalgaruda.o rg/article.php?article $=138705 \&$ val=1342

Novia dan Kusumo (2013). Penerapan Model Pembelajaran Konstruktivisme Berbantuan Concept Map untuk Meningkatkan Hasil Belajar Kimia pada Siswa SMA. Dalam Jurnal Inovasi Pendidikan Kimia. Vol 7 (1), 2013. Tersedia http://download.portalgaruda.o rg/article.php? article=388272\&val=5666\&title=PENERAPAN\%20MODEL\%20PEMB ELAJARAN\%20KONSTRUKTIVISME\%20BERBANTUAN\%20CONCEPT\%20MA P\%20UNTUK\%20MENINGKATKAN\%20HASIL\%20BELAJAR\%20KIMIA\%20PA DA\%20SISWA\% 20SMA

Ruseffendi (1998). Statistika Dasar Untuk Penelitian Pendidikan. Bandung. IKIP Bandung Press. 
Septriani dkk (2014). Pengaruh Penerapan Pendekatan Scaffolding terhadap Kemampuan Pemahaman Konsep Matematika Siswa Kelas VIII SMP Pertiwi 2 Padang. Dalam Jurnal Pendidikan Matematika. Vol 3 (3), 2014.

Setiawati dkk (2015). Pengaruh Model Pembelajaran Kooperatif Thinking Aloud Pair Problem Solving (TAPPS) Berbantuan LKS terhadap Sikap Sosial dan Hasil Belajar Matematika Siswa Kelas VI SLB Negeri Gianyar. Dalam eJournal Program Pascasarjana Universitas Pendidikan Ganesha Program Studi Penelitian dan Evaluasi Pendidikan. Vol 5(1),2015.Tersedia http://pasca.undiksha.ac.id/ejournal/index.php/jurnal_ep/article/view/1544/1200

Stephanus (2014). Implementasi Model Pembelajaran Conceptual Understanding Procedures (CUPs) Berbantuan Maple dan Kooperatif tipe Learning Together (LT) Berbantuan Maple terhadap Kemampuan Pemahaman Konsep Matematis Siswa. Skripsi. Bandung: UNAI.

Suhendar (2014). Upaya Meningkatkan Kemampuan Pemahaman Konsep Matematik Siswa dengan Metode Pembelajaran Thinking Aloud Pair Problem Solving (TAPPS). Skripsi Jakarta: UIN.

Tianingrum dan Sopiany (2017). Analisis Kemampuan Pemahaman Matematis Siswa SMP pada Materi Bangun Ruang Sisi Datar. [Online]. Available: http://sesiomadika.890m.com/Prosiding/64RisnaTianingrumSESIOMADIKA-2017.pdf

Utari dkk (2012). Peningkatan Kemampuan Pemahaman Konsep melalui Pendekatan PMR dalam Pokok Bahasan Prisma dan Limas. Dalam Jurnal Pendidikan Matematika. Vol 1 (1), 2012. Tersedia http://ejournal.unp.ac.id/studen ts/index.php/pmat/article/view/ $1159 / 851$

Widiyastuti dkk (2014). Penerapan Strategi Thinking Aloud Pair Problem Solving (TAPPS) dalam Pembelajaran Matematika Kelas VIII SMPN 11 Padang. Dalam Jurnal Pendidikan Matematika. Vol 3 (1), 2014. Tersedia http://ejournal.unp.ac.id/studen ts/index.php/pmat/article/view/ 1201/893

Zevika dkk (2012). Meningkatkan Kemampuan Pemahaman Konsep Siswa Kelas VIII SMP Negeri 2 Padang Panjang melalui Pembelajaran Kooperatif tipe Think Pair Share disertai Peta Pikiran. Dalam Jurnal Pendidikan Matematika. Vol 1 (1), 2012. Tersedia http://ejournal.unp.ac.id/studen ts/index.php/pmat/article/view/ 1170/862 